AMERICAN JOURNAL BIOTECHNOLOGY AND MOLECULAR SCIENCES

ISSN Print: 2159-3698, ISSN Online: 2159-3701, doi:10.5251/ajbms.2011.1.2.51.56

(C) 2011, ScienceHu $\beta$, http://www.scihub.org/AJBMS

\title{
Effect of propagation media on the germination and seedling performance of Irvingia wombolu (Vermoesen)
}

Dickens Dolor

\author{
Department of Forestry \& Wildlife, Delta State University Asaba Campus, Asaba, Nigeria \\ e-mail: dickensdolor@yahoo.co.uk
}

\begin{abstract}
This study evaluated the effect of media on the germination and seedling performance of Irvingia wombolu. The experiment was conducted at the Teaching and Research Farm of the Delta State University, Asaba Campus, Nigeria. The results revealed a lack of media effect, $(P>0.05)$ on rooting percentage with river sand recording $21.8 \%$, Sawdust $(18.1 \%)$, clayey soil $(17.6 \%)$ and top soil (17.6\%). A pronounced effect of media on leaf area was observed with river sand and topsoil higher $(P=0.05)$ than the rest treatments. Plant height, the number of leaves and dry weight displayed no treatment effect.
\end{abstract}

Keywords: Irvingia wombolu, propagation media, germination, seedling emergence.

\section{INTRODUCTION}

Irvingia wombolu, commonly called bush mango or dika nut is a hardwood multi-purpose tree found in West and Central Africa (Harris, 1996; Ayuk et al., 1999; Lowe et al., 2000; Atangana et al., 2002). The trees provide food, fuel, fibre, medicine, construction and building materials (Ayuk et al., 1999; Leakey, 1999). It is ranked as the most important species for its food and commercial value in Cameroon and West Africa (Leakey, 1999; Ladipo, 2000). Irvingia gabonensis and Irvingia wombolu are the species that produce edible kernels. The fruit of the former has a sweet mesocarp and it is eaten fresh while that of the later is sour and is not consumed locally (Okafor, 1975; Leakey, 1999; Fajimi et al., 2007).

Most of the trees that are at present of great importance to farmers have been growing in the wild, as they have not been domesticated. Constraints to domestication of the species include the long gestation period of seed sown trees ( Moss, 1995; Ladipo et al., 1996), poor germination capacity ( Nya et al., 2000) variability of fruits and kernel characteristics, variability in tree size ( Ladipo et al.,1996, Schreckenberg et al., 2001) and limited knowledge base ( Tchoundjeu et al., 2002). Although bush mango is recently being domesticated, less than 10 percent of the total annual harvest of fruits or kernel is harvested from planted trees while the rest are collected from the natural forests (Ladipo, 2000). Both Irvingia species are found growing wild in the humid lowland forests of tropical Africa in Angola, Cameroon, Central African Republic, Congo, Equatorial Guinea, Gabon and Zaire (Harris, 1996) with I. wombolu extending to Senegal (Ndoye et al.1997, cited by Ainge and Brown, 2001). Irvingia's preferred habitat is undisturbed lowland tropical forest (van Dijk, 1997). According to Okafor (1975), I .gabonensis prefers well-drained sites while $I$. wombolu thrives in wetter conditions. They are also found in compound farms and it is not uncommon to find Irvingia trees protected in cocoa, cola and coffee plantations (Ladipo, 2000).

According to Hartmann et al, (2007), seed germination is influenced by many factors such as the type of substrate used, environmental factors such as oxygen, water, temperature and for some plant species, light. Generally, growth medium has been adjudged to be the most critical factor determining seedling quality in the nursery (Baiyeri and Mbah, 2006), acting as a reservoir for nutrients and moisture (Grower, 1987). The growth medium physical properties can also have a profound effect on the supply of water and air to the growing plant (Baiyeri, 2005). Although propagation of indigenous tree species from seed is inexpensive and usually effective.

The germination requirements for native species are often unknown. As a result of increasing demand for fruits and other non-wood products from the reducing natural forests, the present study aims at developing a protocol for the propagation of Irvingia wombulu by seed to produce seedlings for farmers and to improve food security and income generation. 


\section{MATERIALS AND METHODS}

The experiment was carried out at the Delta State University, Asaba Campus (06 $14^{\prime} \mathrm{N}$ and $\left.06^{\circ} 49^{\prime} \mathrm{E}\right)$ in Oshimili South local Government Area of Delta State, Nigeria. Asaba lies in the tropical rainforest zone with annual rainfall range of $1500 \mathrm{~mm}$ to $1849.3 \mathrm{~mm}$. Mean temperature are $23.3^{\circ} \mathrm{Celsius}$ with a maximum of $37.3^{\circ} \mathrm{Celsius}$. Mean monthly soil temperature at $100 \mathrm{~cm}$ depth and sunshine is $28.3^{\circ} \mathrm{Celsius}$ and 4.8 hours respectively (Asaba Meteorological Centre 2003).

Four hundred fruits of $I$. wombolu were procured from fruit collectors at Ossissa, Delta State. The fruits were depulped and thereafter were cleaned before sowing. The four planting media consisting of topsoil, clayey soil, river sand and composted sawdust were filled into $45 \mathrm{~cm} \times 45 \mathrm{~cm} \times 30 \mathrm{~cm}$ germination boxes. Twenty seeds each were randomly sown in the different media in a completely randomized design. Each treatment was replicated 4 times with daily watering to field capacity. The parameters assessed weekly included germination percentage, plant height, leaf number, and leaf area, seedling biomass production was assessed 8 weeks after sowing.

The seed germination criterion was visible protrusion on the soil surface of at least $0.5 \mathrm{~cm}$ of the cotyledon and hypocotyls of the seedlings. At the end of the experiment, five seedlings from each replicate were randomly selected and uprooted. The uprooted seedlings were then separated into leaf, stem and root components and dried in an electric even at 70 degree Celsius until a constant weight was obtained for biomass assessment.

Data collected were subjected to analysis of variance (ANOVA) and significant means were separated by Fisher's Least Significant Difference (LSD) at 5\% level of probability, using Genstat 3 Discovery edition (Genstat 2007). Prior to ANOVA, all percentage data were arcsine transformed, plant height, leaf area, and dry weight data were log transformed while the number of leaves was square root transformed, (Gomez and Gomez 1984).

Prior to sowing, samples of the various media namely top soil, clayey soil, river sand and composted sawdust were collected, air dried, crushed and packed in labelled air-tight bags for analysis. The analytical procedure used is as contained in the laboratory manual of the International Institute for Tropical Agriculture (Juo, 1979). The soils were analysed for particle size distribution, organic carbon, soil $\mathrm{pH}$, available phosphorus, cation exchange capacity (CEC) and exchangeable cations.

\section{RESULTS}

Table 1: Pre-planting soil media analysis

\begin{tabular}{lllll}
\hline $\begin{array}{l}\text { Soil characteristics } \\
\text { Particle size distribution \% }\end{array}$ & Top soil & Clayey soil & River sand & Composted sawdust \\
\hline Sand & 85.52 & & & \\
Silt & 6.0 & 2.0 & 96.5 & - \\
Clay & 8.48 & 95.2 & 2.3 & - \\
Textural class & Loam soil & Clay & Sand & - \\
pH $\left(\mathrm{H}_{2} \mathrm{O}\right)$ & 6.24 & 6.12 & 5.82 & 6.35 \\
Organic matter $\left(\mathrm{g} \mathrm{Kg}^{-1}\right)$ & 28.25 & 12.38 & 0.05 & 35.48 \\
Available P $\left(\mathrm{mg} \mathrm{Kg}^{-1}\right)$ & 9.78 & 22.43 & 0.35 & 23.76 \\
Exchangeable cations & & & & \\
$\left(\mathrm{Cmol} \mathrm{Kg}^{-1}\right)$ & & & & \\
$\mathrm{Ca}^{++}$ & 5.2 & 7.5 & 3.2 & 8.74 \\
$\mathrm{Mg}^{++}$ & 1.75 & 3.3 & 0.57 & 1.47 \\
$\mathrm{~K}^{+}$ & 0.12 & 0.25 & 0.26 & 0.37 \\
$\mathrm{Na}^{+}$ & 0.02 & 0.03 & 0.03 & 0.20 \\
$\mathrm{CEC}\left(\mathrm{Cmol} \mathrm{Kg}^{-1}\right)$ & 14.50 & 23.15 & 15.50 & 25.20 \\
\hline
\end{tabular}

The effect of media on germination percentage was significant $(P<0.04)$ with clayey soil recording lower value $(14 \%)$ than the rest treatments i.e. topsoil
$(18 \%)$, river sand (21\%) and sawdust (20\%) at Week 3 when germination commenced, (Table 2). The difference between the treatments tended to diminish 
thereafter such that by Week 4 there was no treatment effect $(P>0.05)$, with river sand recording $24 \%$, sawdust $(22 \%)$, topsoil $(21 \%)$, and clayey soil (19\%). This trend was maintained till the final assessment at Week 8 , with germination percentage ranging from $22 \%$ to $26 \%$ in top soil and river sand respectively.

Plant height was unaffected by media $(P>0.05)$. At Week 5, plant height values for the different media are as follows: clayey soil $0.43 \mathrm{~cm}$, sawdust $0.51 \mathrm{~cm}$, river sand $0.52 \mathrm{~cm}$ and topsoil $0.52 \mathrm{~cm}$. Similar trend was displayed in Week6 and Week 7. At week 8, plant height ranged between $0.50 \mathrm{~cm}$ to $0.59 \mathrm{~cm}$ in clayey soil and river sand respectively (Table 3 ).

Similarly number of leaves was unaffected by media $(P>0.05)$. At Week 5, topsoil recorded the highest value for number of leaves (1.16), river sand (1.15), sawdust (1.13), and clayey soil (1.09). The values recorded by the various treatments at Week 6 are as follows: topsoil (1.29), clayey soil (1.28), river sand (1.28) and sawdust (1.22). This trend continued till the final assessment at Week 8 when values ranged from 1.34 to 1.36 in sawdust and river sand respectively (Table 4 ).

Leaf area was unaffected by media at Week 5 $(P>0.05)$ with values ranging from $0.42 \mathrm{~cm}^{2}$ to 0.51 $\mathrm{cm}^{2}$ in clayey soil and river sand respectively. A similar trend was recorded in Week 6 . At Week 7 , sawdust recorded significantly $(P=0.05)$ lower leaf area than the other treatments. Treatment effect is highly significant $(P=0.01)$ at Week 8 with river sand recording significantly higher values than sawdust, though not different from the other treatments, which were in turn not different from sawdust (Table 5).

Leaf dry weight was unaffected by media $(P>0.05)$ with values ranging from $0.16 \mathrm{~g}$ to $0.18 \mathrm{~g}$ in sawdust and river sand respectively. Similarly, stem dry weight were unaffected by media, (Table 6 ).

Table 2: Effect of media on germination percentage of Irvingia wombolu

\begin{tabular}{llllllll}
\hline & \multicolumn{7}{l}{ /weeks after sowing (WAS) } \\
Media & 2 & 3 & 4 & 5 & 6 & 7 & 8 \\
\hline Top soil & 9.1 & 18.13 & 21.08 & 22.25 & 22.25 & 22.25 & 22.54 \\
Clayey soil & 9.1 & 13.29 & 18.68 & 22.25 & 22.58 & 22.58 & 22.58 \\
River sand & 9.1 & 20.73 & 23.7 & 26.44 & 26.44 & 26.44 & 26.74 \\
Sawdust & 9.1 & 20.47 & 22.46 & 22.77 & 23.05 & 23.05 & 23.05 \\
LSD .05 & ns & 5.55 & ns & ns & ns & ns & ns \\
\hline
\end{tabular}

Table 3: Effect of media on plant height of Irvingia wombolu

\begin{tabular}{lllll}
\hline & /weeks after sowing (WAS) & & \\
Media & 5 & 6 & 7 & 8 \\
\hline Top soil & 0.52 & 0.57 & 0.57 & 0.57 \\
Clayey soil & 0.43 & 0.49 & 0.50 & 0.50 \\
River sand & 0.52 & 0.58 & 0.59 & 0.59 \\
Sawdust & 0.51 & 0.55 & 0.55 & 0.56 \\
LSD .05 & $\mathrm{~ns}$ & $\mathrm{~ns}$ & $\mathrm{~ns}$ & $\mathrm{~ns}$ \\
\hline
\end{tabular}

Table 4: Effect of media on number of leaves of Irvingia wombolu

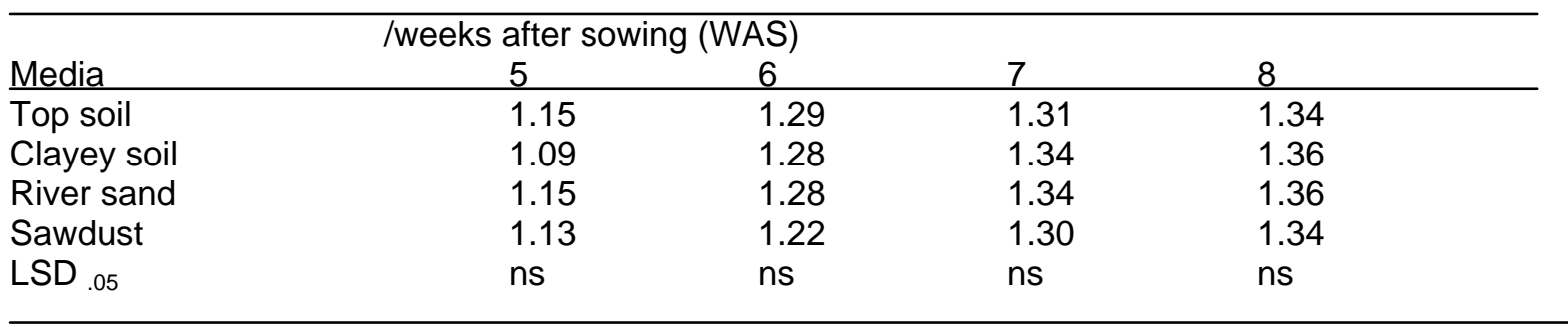


Am. J. Biotechnol. Mol. Sci., 2011, 1(2): 51-56

Table 5: Effect of media on leaf area of Irvingia wombolu

\begin{tabular}{lllll}
\hline & /weeks after sowing (WAS) & & \\
Media & 5 & 6 & 7 & 8 \\
\hline Top soil & 0.50 & 0.63 & 0.64 & 0.64 \\
Clayey soil & 0.42 & 0.61 & 0.62 & 0.62 \\
River sand & 0.51 & 0.64 & 0.64 & 0.65 \\
Sawdust & 0.47 & 0.58 & 0.56 & 0.56 \\
LSD .05 & ns & ns & ns & 0.05 \\
\hline
\end{tabular}

Table 6: Effect of media on dry weightof Irvingia wombolu

\begin{tabular}{lllll}
\hline Media & $\begin{array}{l}\text { Dry weight }(\mathrm{g}) \\
\text { LDWT }\end{array}$ & SDWT & RDWT & TOTAL DWT \\
\hline Top soil & 0.17 & 0.16 & 0.07 & 0.23 \\
Clayey soil & 0.16 & 0.15 & 0.08 & 0.26 \\
River sand & 0.18 & 0.16 & 0.07 & 0.28 \\
Sawdust & 0.16 & 0.14 & 0.07 & 0.25 \\
LSD .05 & 0.03 & $\mathrm{~ns}$ & $\mathrm{~ns}$ & $\mathrm{~ns}$ \\
\hline
\end{tabular}

\section{DISCUSSION}

The results obtained from this study indicate that Irvingia wombulu did not respond to media treatments. Medagoda and Weerawardana (2007) also recorded a lack of media effect on seed germination of several members of Macadamia species/cultivars. This result contrasted the findings of Sadhu (1989) who stated that quartz sand comprising mainly silica is most suitable for propagation purpose and Haque et al. (1992) who obtained a greater seedling emergence rate of rice (Oryza sativa) in seedbeds with coarse aggregates and concluded that crop establishment was not affected by soil structure. The lack of pronounced effect of growth media on germination observed in this study may be explained by Diaz-Zorita et al. (2005), and Cernac et al. (2006) who stated that germination and seedling emergence is independent of soil nutrient status, but rather depends totally on the cotyledons still attached to the seedling which are rich in stored food reserves until the seedling becomes autotrophic and the ability of the seedlings to utilize these food reserves. This assertion contrasted sharply with the findings of Okunomo et al. $(2004,2009)$ who obtained a higher germination percentage in top soil with Dacryodes edulis and Persea americana respectively, citing the presence of adequate nutrients for germination and growth in topsoil. The seedbed temperature may be a major reason for the apparent high germination recorded in river sand. Schneider and Gupta (1985) speculated that time to corn emergence was most sensitive to soil temperature and was successively less influenced by soil water potential and soil aggregate size. Sand warms up more rapidly leading to increased biochemical activities which translate to increased germination (Brady and Weil, 1999). These findings were earlier attested to by Tisdale and Nelson, (1975) who stated that temperature directly affects the plants functions of photosynthesis, respiration, cell wall permeability, absorption of water and nutrients transpiration, enzyme activity and protein coagulation.

Pending further investigation, it is concluded that growth media did not influence the propagation of this species in the nursery.

\section{REFERENCES}

Ainge, L. and Brown, N. 2001. Irvingia gabonensis and Irvingia wombolu. A State of the Knowledge Report. CARPE.

http://carpe.umd.edu/resources/Dorcuments/reportaingebrown2001pdf/wiew.20K

Asaba Meteorological Centre 2003. National meteorological report. Meteorological Bulletin. Lagos, Nigeria.

Atangana. A. R., Ukafor V., Anegbeh, P., Asaah, E., Tchoundjeu. Z,, Fondoun, J. M., Ndoumbe $M$ and Leakey, R.R.B. 2002. Domestication of Irvingia gabonensis: 2. the selection of multiple traits for potential cultivars from Cameroon and Nigeria. Agroforestry Systems 55: 221-229. 
Ayuk, E.T., Duguma, B., Franzel, S., Kengue, J., Mollet, S.M., Tiki-Manga, T. and Zenkekeng, P., 1999. Uses, management and economic potentials Irvingia gabonensis in the humid lowlands of Cameroon. Forest Ecology and Management, 113: 1-9.

Brady, C.N. and Weil, R.R. 1999. The nature and properties of soils. Prentice Hall, N. Jersey pp 881.

Baiyeri KP 2005. Response of Musa Species to MacroPropagation: II: The effects of genotype, initiation and weaning media on sucker growth and quality in the nursery. Afr. J. Biotechnol. 4(3): 229-234.

Baiyeri KP., and Mbah BN: 2006. Effects of soilless and soil based nursery media on seedling emergence, growth and response to water stress of African breadfruit (Treculia Africana Decne). African Journal of Biotechnology, 5: 1405-1410.

Cernac, Alex, Andre, C., Hoffmann-Benning, S. and Benning, C., 2006. WRI1 is required for seed germination and seedling establishment ${ }^{1}$. Plant Physiology 141: 745-757.

Diaz-Zorita, M., Grove, J.H. and Perfect, E. 2005. Soil fragment size distribution and compactive effort effect on maize root seedling elongation in moist soil. Crop Science. 45: 1417-1426.

Fajimi, O., Sarumi, M.B., Olayode, M.N., Gamra, E.O. and Sanusi, S.I. 2007. In-vitro propagation of Irvingia gabonensis. African Journal of Biotechnology 6(8): 976-978.

Genstat, 2007. Genstat discovery edition 3. Lawes Agricultural Research Trust, Rothamsted Experimental Station.

Gomez, K.A. and Gomez, A.A. 1984. Statistical procedures for agricultural research $2^{\text {nd }}$ edition. John Wiley and Sons, N.Y. 680pp.

Grower, S.T., 1987. Relations between mineral nutrient availability and fine root biomass in two Costa Rican tropical wet forests. Hypothesis Biotropica, 19: 171175.

Harris, D. J. 1996. A revision of the Irvvingiaceae in Africa. Bull . Jard . Bot . Belg . 65: 143-196.

Hartmann H . T ., Kester, D . E. Davies, F. T., and Genve, R. I., 2007. Hartmann and Kester's plant propagation, principles and practices. Seventh edition. Prentice-Hall of India Private limited pp880.

Haque, A., Hamid, A., Islam, M.T. and Mohinddin, M. 1992. Seedbed characteristics and seedling depth effect on emergence and seedling vigour of upland rice. Journal of Agronomy and Crop Science 168: 61-64.

Juo, A.S. 1979. Selected methods for soil and plant analysis. IITA Manual, series no 1. 70p.
Ladipo, D.O., 2000. Harvesting of Irvingia gabonensis and Irvingia wombulu in Nigerian forests; potentials for the development of sustainable systems. Paper presented at the Seminar Harvesting of Non-Wood Forest Products, held at Menemen-Izmir, Turkey on 2-8 October 2000. http://www.fao.org/ documents/show_cdr.asp?url_file=/ DOCREP/005/Y4496E/ Y4496̄E32.htm.

Ladipo, D.O., Fondoun, J.M and Gana, N., 1996. Domestication of the bush mango (Irvingia spp) : Some exploitable intra-specific variation in West and Central Africa. In: Domestication and Commercialization of Non-Timber Forest Products for Agroforestry (eds.) Leakey, R.R.B., Temu, A.B., Melnyk, M. and Vantomme, P. Non-Timber Forest Products Paper 9, FAO Rome. Pp 193-206.

Leakey, R.R.B. 1999. Farmers top priority fruit trees. Agroforestry Today. 11(3-4): 11-15

Lowe, A.J.A., Gillies, C.M., Wilson. J. and Dawson, I.K. 2000. Conservation genetics of bush mango from central/west Africa: Implications from random amplified polymorphic DNA analysis. Molecular Ecology 9: 831-841.

Medagoda, I. and Weerawardana, J.M.T.T., 2007. Studies on seed germinability, propagation and taxonomic features of Macadamia germplusm. Sri Lankan J. Agric. Sci. 42: 105-112.

Moss, R.1995. Unexploited tree crops: components of productive and more sustainable farming systems. Journal for Farming Systems Research Extension 5(1): 107-117.

Ndoye, O.M., Ruiz-Perez, and Ayebe, A., 1997. the markets of non-timber forest products in the humid forest zone of Cameroon. Rural Development Forestry Network. Paper No. 22c ODI. London, UK. 25pp.

Nya P. J., Omokaro D. N. and Nkang A. E. (2000). Comparative studies of seed morphology, moisture content and seed germination of two varieties of Irvingia gabonensis. Global J. Pure \& Appl. Sci. 6(3): 375-378.

Okafor, J.C. 1975. Varietal delimination in Irvingia gabonensis (Irvingiaceae). Bulletin du Jardin Botanique Nationale de Belgique 45(1-2): 211-221.

Okunomo, K., Oghenerhoro, E.O. and Ojeifo, I.M. 2004. Effect of soil type on the germination and growth of Darcryodes edulis (Don. G. Lam H.J.). Journal of Sustainable Tropical Agricultural Research 12: 46-50.

Okunomo, K., Ogisi, D.O. and Bosah, B.O. 2009. Effect of growth media on germination and seedling growth of Persea americana (Mill). Journal of food,Agriculture and Environment. 7(1): 111-113.

Sadhu, M. K. 1989. Plant propagation. New Age International (P) Ltd. New Delhi. Pp 287 
Schreckenberg, K., Leakey, R.R.B and Z. Tchoundjen 2001 opportunities and constraints faced by resource - poor farmers in investing in the planting and improvement of indigeneous trees for income generation. European Tropical Forest Research Network Newsletter No 32. www.Etfrn/newsletter/nl32-01p6.html.

Schneider, E.C. and Gupta, S.C. 1985. Corn emergence as influenced by soil temperature, matrix potential and aggregate size distribution. Soil Soc. Am. J. 49: 415422.

Tchoundjeu, Z., Duguma, B., Marie-Laure, T. and MarieLaure, N. 1997. The domestication of indegenious agroforestry trees of West and Central Africa. CARPE: Limbe Non-Wood Forest Products Workshop. Web address: http:// carpe.gecp.virginia.edu/products/products2a.asp

Tchoundjeu, Z., Kengue, J. and R.R.B. Leakey 2002. Domestication 71 of Darcryodes edulis: state-of-theart. Forests, Trees and Livelihoods 12: 3-13.

Tisdale, S. and Nelson, W. 1975. Soil fertility and fertilizers. Macmillan Publishing Co. Inc. NY. Pp694.

van Dijk, J.F.W. 1997. An assessment of non-wood forest resources for the development of sustainable commercial extraction. CARPE: Limbe Non-Wood Forest Products Workshop. Web address: http://carpe.gecp.virginia.edu/products/products2a.asp 